Slavica Stevanovic, BSc. Psychology, York University, 2005

\author{
A Major Research Paper \\ presented to Ryerson University \\ in partial fulfillment of the requirements for the degree of \\ Master of Arts \\ in the Program of \\ Immigration and Settlement Studies
}

Toronto, Ontario, Canada, 2006

(C) 2006 Slavica Stevanovic 
UMI Number: EC53540

INFORMATION TO USERS

The quality of this reproduction is dependent upon the quality of the copy submitted. Broken or indistinct print, colored or poor quality illustrations and photographs, print bleed-through, substandard margins, and improper alignment can adversely affect reproduction.

In the unlikely event that the author did not send a complete manuscript and there are missing pages, these will be noted. Also, if unauthorized copyright material had to be removed, a note will indicate the deletion.

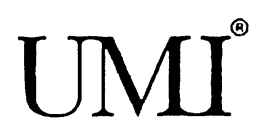

UMI Microform EC53540

Copyright 2009 by ProQuest LLC

All rights reserved. This microform edition is protected against unauthorized copying under Title 17, United States Code.

ProQuest LLC

789 East Eisenhower Parkway

P.O. Box 1346

Ann Arbor, MI 48106-1346 
I hereby declare that I am the sole author of this major research paper.

I authorize Ryerson University to lend this paper to other institutions or individuals for the purpose of scholarly research.

Słavica Stevanơvic

I further authorize Ryerson University to reproduce this paper by photocopying or by other means, in total or in part, at the request of other institutions or individuals for the purpose of scholarly research.

STavica Stevanovic 


\title{
RECOGNITION OF RELIGIOUS GROUPS IN MULTICULTURAL EDUCATION
}

\author{
Slavica Stevanovic, 2006 \\ Master of Arts \\ Immigration and Settlement Studies \\ Ryerson University
}

\begin{abstract}
[This paper discusses recognition of religious minorities in multicultural education by conducting socio-political analysis of religion as a construct of group identity and a social regulator, and educational secular public space. Current multicultural educational practices are criticized for failing to actively promote social change and create alternative spaces to that of secular Eurocentric education. The paper concludes that the issue of public funding of independent religious schools is a matter of both parents' individual rights and groups' rights to have their cultural identity recognized and equally treated under the law. Anti-racist discourse and Afrocentric education are introduced as one alternative to hegemonic, mono-centric framework in education that not only recognizes minorities in public institutions but also acknowledges their worth.]
\end{abstract}

Key Words: politics of identity; religion; school as a secular space; multicultural education; Afrocentric education. 


\section{TABLE OF CONTENTS}

$\begin{array}{ll}\text { Introduction } & \mathbf{1}\end{array}$

Historical overview of the debate on the public funding of religious schools 2

$\begin{array}{ll}\text { Theoretical framework } & 5\end{array}$

$\begin{array}{ll}\text { Methodology } & 7\end{array}$

$\begin{array}{lr}\text { Identity Politics } & 8\end{array}$

- Individualized Self $\quad 8$

- Postmodern, Collective Self 10

$\begin{array}{ll}\text { Religion and social identity } & 13\end{array}$

$\begin{array}{ll}\text { Secularization of educational public space } & 17\end{array}$

- Rationalization of public space 18

$\begin{array}{ll}\text { Diversity in public schools: Historical perspective } & 22\end{array}$

$\begin{array}{ll}\text { Current policies of religious accommodation } & 25\end{array}$

$\begin{array}{ll}\text { Criticism of current practices in multicultural education } & 28\end{array}$

- Administration and school structure 29

- Teachers' perception and attitudes 31

- Peer pressure 33

- Xenophobia, Isalmophobia and Racism 34

- Curriculum 35

- Politics of multicultural education 36

Critical theory, critical pedagogy and culturally relevant teaching 37

- $\quad$ Language of critical pedagogy 38

An alternative: Anti-racist (anti-oppressive) education 40

$\begin{array}{ll}\text { Discussion } & 43\end{array}$

$\begin{array}{ll}\text { Conclusion } & 46\end{array}$

$\begin{array}{lr}\text { References } & 48\end{array}$ 


\section{Introduction}

Canada has become more diverse than ever before as the direct consequence of immigration policy. Change in immigration policy in 1967 and implementation of the Norms of Assessment points system with the purpose of eliminating discrimination practices in the admission process caused the shift from exclusively European immigration to immigrants from South Asia, Africa and Latin America (Kelley and Trebilcock, 1998). In the following years immigration from Asia and the Middle East led to the increase of Muslim, Sikh, Hindu and Buddhist population (Kelley and Trebilcock, 1998). While Roman Catholic and Protestant religious membership both declined by almost $10 \%$, Hindu and Sikh population increased by $89 \%$ and Buddhist by $84 \%$ (Statistics Canada, 2003). Muslims have been the fastest growing religious group with approximately 579,640 members living in Canada. According to 2001 Census Data, there are 352,530 Muslims in Ontario, which is more than $100 \%$ increase from 1991 (Statistics Canada, 2001). Growing changes in population have presented significant challenge for Canadian public institutions to accommodate religiously, linguistically and culturally diverse populations (Bramadat, 2005).

Recognition of minority group rights in public educational institutions has been an issue of considerable public debate since the constitution in Canada back in 1846 when French and English were the only constitutional actors (Kelley and Trebilcock, 1998). In recent years, political discourse on group rights and group recognition in public institutions, involved politics of identity (Taylor, 1992; Kymlicka, 1998), cultural pluralism and public sphere (Yasmeen \& Gabriel, 2002; Fraser, 1992), religion as the major factor in cultural self-preservation (Bramadat, 2005; White, 2003); and role of state in protection of cultural minorities (Kymlicka, 1995). Debate about recognition of religious minorities in public schools requires reflection on all of the above mentioned issues. 


\section{Historical overview of the debate on funding of religious schools}

The story of public funding for religious schools begins prior to Confederation in 1867 when establishment of the British North American Act united Upper Canada (now Ontario) dominated by English protestant and Lower Canada (now Quebec) dominated by Catholic French into Dominion Canada (Kelley and Trebilcock, 1998). The Common School Act of 1841 provided for the recognition of religious minorities adhering to religion different from that of the majority of population allowing them to set up a separate school system, which could also participate in the provincial fund for common schools. The outcome of this Act was establishment of a public Catholic system complemented by a separate Protestant system in Quebec; in Ontario the opposite was true (Bowman, 1991). Public funding for separate religious schools served as a 'Constitutional compromise' that guaranteed state protection against dominant culture. Without extending separate school rights for Catholics in Ontario and Protestants in Quebec, confederation could not have occurred (Bowman, 1991).

Section 93 of the Constitutional Act, $1867^{1}$ assigns exclusive responsibility for the law in education to each province according to four provisions stated in the section that place limits on provincial power. Section 93(1) clearly limits provincial legislation that could affect denominational rights: "Nothing in any such Law shall prejudicially affect any Right or Privilege with respect to Denominational Schools which any Class of Persons have by Law in the Province at the Union" (s. 93(1), The Constitution Act). The privileged right of Catholic and Protestant religious schools built into the Constitution Act represents a fundamental part of the Confederation promise. Although the special status given to Catholic schools in Ontario is a

\footnotetext{
1 The Constitutional Act, 1867; Retrieved on Sep.20, 2006 from web-site: http://www.solon.org/Constitutions/Canada/English/ca_1867.html
} 
constitutional obligation, recent extension of the public funding to the Roman Catholic schools seems to reflect political will rather than historical circumstances (Shapiro, 1986).

Christianity had been the essential element of Canadian public schools until new values of pluralism and democracy led to reorganization of schools towards more secularized system (White, 2003). 'De-Christianization' of public education and secularization movement increased with the establishment of Charter of Rights and Freedoms in 1981 that "guaranteed freedom of conscience and religion and equality under the law without discrimination based on religion" (Seljak, 2005, p.181). However, Roman Catholic and Protestant schools remained the part of publicly supported school system as granted by the Constitution Act, 1867 and protected in section 29 of the Charter stating that constitutionally guaranteed rights to denominational education cannot be challenged (Dolmage and Dickinson, 1996; Seljak, 2005).

The special treatment of Christians reflected in funding of their separate school system and recognition of Christian religious holidays in public secular system was challenged in the Ontario court under the rhetoric of official Multiculturalism (Dolmage and Dickinson, 1996; Callan, 2000). Several cases invoked the right for religious freedom and equality under the Charter and the protection and maintenance of group identity. Multicultural Act, passed in 1988 supported by the Section 27 of the Charter which reads [the Charter] "shall be interpreted in a manner consistent with the preservation and enhancement of the multicultural heritage of Canadians" indicated that protection of minority groups was the business of federal government (Yasmeen \& Gabriel, 2002, p.110). Adler v. Ontario case, argued that the equality and rights guaranteed by law serve to protect vulnerable minority groups against assimilation pressure from the majority; therefore, equal benefits for non-Christian religious schools is the matter of preserving the culture and the recognition of values of minority cultures (Callan, 2000). In 1996, Ontario courts ruled that government is not responsible for funding other religious schools 
because: 1) Funding for Catholic schools is protected by Canadian Constitution and cannot be challenged, 2) Ontario public schools are secular in nature and do not promote any specific religious beliefs (White, 2003).

Ethnic groups that consider religion to be fundamental part of their identity are challenging inclusiveness of secular public schools and ability of public schools not only to accommodate diverse religious practices but also to teach a curriculum that responds to needs and beliefs of religiously motivated parents (Azmi, 2001; Zine, 2000). The distinctiveness in ideology between secular liberalist and religiously oriented minority groups led to establishment of private religiously based schools. For example, the Jewish community in Toronto had 32 Jewish day schools by the end of 1999 serving about 9120 students, a $35 \%$ increase from 1989 (Azmi, 2001). Similarly, the Muslim community has established a total of 35 independent schools across Ontario (Zine, 2006).

Recognition of ethnic minorities within public institutions has been a subject of debate and disagreement among scholars, politicians and ethnic minority groups. Despite the continuous struggle of religious minorities to secure public funding for religiously based schools, Ontario Government has been reluctant to do so even after being repeatedly accused of discriminatory practices and failure to enact the principles of Multicultural Act (White, 2003; Seljak, 2005; Callan, 2000; Azmi, 2001). Although the principles of multiculturalism as entrenched in the Multicultural Act have not changed, interpretation and implementation of the Act in regard to protection of cultural groups have varied over times (Kymlicka, 1998; Harper, 1997). Multiculturalism as the nation building ideology has been struggling to reconcile, on the one hand, the notion of liberalism focused on individual rights and politics of free-choice, selfinterest and progress and on the other hand recognition of culture, collective and community interest (Fleras \& Elliot, 2002). 


\section{Theoretical framework:}

The purpose of this paper is to examine the argument in the socio-political discourse on multicultural education concerning not only individuals as singular, independent entity but also individuals as bonded to, inseparable from and dependent on the group. The focus is examination of educational politics in secular public schools and the treatment of diverse religious identities in such space through interrelated themes: development and social construction of identity, religion as a social identity construct, politics of group identity, and the multicultural approach to diversity in education.

Examination of relationship between identity and religion is conducted by reviewing political (Taylor, 1992); social (Mead, 1934; Cushman, 1998); developmental (Bernhard, 1995) and cultural capital (Kilbride, 2000) theories of social identity. Drawing on the literature from the sociology of religion (Durkheim, 1915; McGuire, 1997; Herbert, 2003), I will argue that religion as a social force and social bonding power is an important factor in social cohesion as well as social conflict and as such cannot and should not be excluded from public space and civic education. I then focus on the problem arising from conceptualization of public schools as a secularized, neutral public space and argue that public support for separate religious schools is a matter of the rights of individual parents to demand that their group identities be equally treated under the law. Furthermore, current policies and practices of religious accommodation in public education will be interrogated in the light of culturally relevant pedagogy and anti-racist education (Ladson-Billings, 1995; Giroux, 2003; Freire, 1978, Dei, 1996, 2000; Zine, 2002, 2003).

In a world that is becoming more globalized but where ethno-religious conflicts are still the most common reason for political violence, engaging in a discussion of the role of religion in civic life and public sphere as well as its role in ' the politics of identity' (Taylor, 1992), is 
crucial for development of tolerant pluralistic society. I argue that any school is the shared responsibility of government and community; therefore separate religious schools should receive funding from the government that would allow it to get involved in educational practices to ensure that curriculum is inclusive of educational standards, democratic citizenship education and fair treatment of other religions. 


\section{Methodology: Literature reviews}

Psychological, sociological and political literature on identity, secularism, minority rights, multicultural education and anti-racist education has been researched. Following data bases: Academic Search Premier, Scholar Portal, ERIC, ProQuest, PsycInfo; and websites: Statistic Canada, Ontario Ministry of Education, TDSB (Toronto District School Board), Catholic School Board; are used as a research tools. Articles on identity were selected and organized according to two criteria: one is a modern, scientific perception of identity and the other is social and cultural view of identity construction. Political and sociological articles on public sphere, secularism and minority rights were selected by their relevance to inclusion of social identity in educational institutions. Articles on multicultural education were mostly chosen from the book edited by Sleeter and McLaren (1995) 'Multicultural education, critical pedagogy, and the politics of difference' and references found in the articles herein. The book offers good background and an overview of articles and findings focused on political aspect of education and the current issues concerning multicultural education. One disadvantage in referring to this book is that it is entirely based on the research done in the United States. However, this problem is remedied by discussion of two Toronto based researchers in education George Dei and Jasmine Zine.

Overall, the paper is largely theoretical, examining, interrogating and challenging concepts such as identity, religious affiliation, public space, and multicultural education that are often used as a part of operational definitions in quantitative analysis. However, empirical data offers an important insight into the debate and should be included in further studies and debates. 


\section{Identity politics}

In order to understand how conceptualization of identity plays out in the politics of group recognition in public institutions, we need to engage sociological as well as psychological insights on the construction and development of identity. Identity is political (Cushman, 1995; Taylor, 1992), and school as a site of identity construction and knowledge reproduction is a political institution (Freire, 1978; Kymlicka, 2001).

\section{Individualized self}

Some arguments against public funding for minority religious schools are rooted in the philosophy of liberal citizenship and universality of human nature. According to this view the role of common public education is to promote common values necessary for the development of democratic, liberal citizens (Spinner-Halev, 2000). This view is based on earlier modern understanding of identity as fixed, universal, independent and singular (Peek, 2005).

Development of psychoanalysis asserted that self was something unconscious, hidden inside the person and fully realized only through an extensive therapy. According to Baumeister \& Muraven, (1996) the quest for this inner self has set the stage for self-knowledge that turned into a major value base: "Modern Western individual often perceives a moral imperative in the pursuit of self-interest and self-actualization that is largely unprecedented" (p. 410). The meaning and moral value of such self-contained individual is inwardly generated and monologically understood (Taylor, 1992). The emergence of the masterful, bounded self, separated from community, tradition and collective meaning, yearning for individual growth, and fulfillment and realization led to consumerism and capitalism (Cushman, 1995). Murtadha (1995) points out that "American preoccupation with individual advancement is mirrored in schools which promote competitiveness and singular academic achievement" (p. 364). Values of 
individualized self have worked their way into curriculum, structure and environment of public schools (Seljak, 2003).

The idea that a true human nature can be found in any one individual by 'peeling off' all other particular and social identities is reflected in the notion of universality of human nature (Lopston, 2001). According to this view politics of identity should focus on the universal human nature and public institutions should promote and nurture this universal aspect of identity rather than particular social identities (Callan, 2000). Such a political stand is reflected in common educational institutions where individuals are stripped off any cultural values and meanings and socialized into universal citizenship (Bramadat, 2005). The common values reflected in education are the values of liberalism itself: individualism, autonomy, reason and universality (Seljak, 2003; Bramadat, 2005). Kymlicka (2001) warns that while we tend to believe that these values are universal and neutral, in fact they are expression of a particular cultural and national identity.

Besides socializing children into the values of liberalism, common public schools serve to educate youth into the skills and knowledge compatible with capitalist economy (Seljak, 2005). Côte (1996) argues that socializing pressure to discover one's identity through image consumption and immediate-gratification orientations is particularly high for children who reject their culture of primary socialization and have no guidance in their identity formation. Formation of a stable social identity based on social responsibilities and commitments became increasingly problematic as the tie between individuals and their communities weakened (Côte, 1996).

This type of self-centered behavior that has been deemed universal is contradictory to traditional conceptualization of morality that served to restrain self-interest for the benefits of common good (Baumeister \& Muraven, 1996). Taylor (1992) claims this atomistic view of individuals is reflected in contemporary politics, for example in the Charter of Rights and 
Freedoms which has been developed to protect individual rights over the possibly oppressive goals of society. The concern was that particular identities "will take public precedence over our more universal identity as persons, deserving of mutual respect, civil and political liberties, and decent life chances simply by virtue of our equal humanity" (Guttman, 1992, p.7).

\section{Postmodern, Collective Self}

Postmodernists disagree with autonomous notion of identity. Hull argues that "individual identity is the process of realization of self in the social situation in which it arises" (Procter, 2004, p. 200). Thus, self is generated through dynamics of social process and individual reflections of that process by which it is constantly being re-invented. Social interaction is not only a fundamental force in the construction of self but also makes self-reflection possible. Mead (1934) developed a theory of reflective self that arises in the process of social interaction which gives the illusion of an individualized and self-generated identity because once the self is formed by social interactions it becomes an essential factor in the further development of that process ( $\mathrm{p}$. 226).

Taylor (1992) uses the same argument to show that identity is fundamentally dialogical social process. All modes of expression whereby we construct our identities: language, body language, artistic expressions are learned through interaction with others. Our identities are, according to Taylor (1992) defined "in dialogue with, sometimes in struggle against, the things our significant others want to see in us" (p. 34). The significant others, in the social terms, are people who matter to us: family members, friends, community. Critical theory also acknowledges that individuals are situated within the larger social context. "Structure and agency are inseparable, individual agents... are always structurally situated, and thus human agency is itself socially structured. Social structures reach in the minds and even the hearts of individuals 
to shape their attitudes, motivations, and worldviews. Structural determination is thus inscribed in the very core of human agency" (Chen, 2005, p.15).

Similarly, Bernhard (1995) questions the assumptions of universal construct in human development. She argues for 'cultural-contextual approach' or 'fundamental heterogeneity approach' to human development that recognizes social and cultural influences in human development. "Such a focus on differences is intended to stress the fact that there is no clear line between the individual and his/her environment" (p.7). Cultural-contextual approach to human development offers new insight into the interconnectedness of social, cultural and personal development of human emotions, cognition and behavior. Personal identity is according to cultural identity theory, contingent on social relations, norms and values (Côte, 1996). If cultural or social identity is inseparable from the way we not only understand and perceive our selves but also form the process of our unconscious development of identity, then the assumptions that common human nature can be isolated from its particular manifestation are questionable.

To respect the rights of individuals, therefore means to recognize and respect cultural and social identities that are inseparable part of our identity. My intention is not to argue for group rights to take precedence over individual rights in political realm as some illiberal multiculturalists do (Cohen-Almagor, 2001). I agree with Taylor (1992) that the recognition of cultural identity and its protection must be juxtaposed to individual rights and freedoms.

Right to choose education for their children is individual right of parents (Callan, 2000). Right to educate children in the institution that reflects children's social identities is not only the right of the group to be publicly recognized but also right of individuals to have their social identities recognized in public institutions. Participation in public institutions, particularly schools, depends on the ability of an institution to reflect one's identity (Sikkink, 1999; Dei, 1996). Taylor (1992) argues that recognition of ethnic identities is not enough. "We must not 
only recognize the equal value of different cultures; that we not only let them survive, but acknowledge their worth" (64). This argument is found in postcolonial discourse about the necessity to empower colonized people to change the imposed self-image of inferiority and subjugation. Gorge Dei $(1995,2000)$ asserts that damaged self-image and ethnocentric education contribute to the failure and drop-out experience of education among Blacks. He argues for separate public schools with Afrocentric curricula that will include and appreciate African culture and history. I will return to this point in the discussion of anti-colonial discourse in multicultural education. 


\section{Religion and social identity}

Religion plays a significant role in construction of social identity. Numerous studies have explored the role of religion in group identity, focusing on the connection between religion and ethnic identity and the importance of religion for development of second generation identity (Chong, 1998; Ebaugh \& Chafetz, 2000; Hammond, 1988). Religion can assume greater importance for immigrants in the new country than it had been at home as it serves to resolve adjustment problems and re-establish familiar relations (Peek, 2005). One explanation of why religion becomes important basis for identity is the role it plays in society. Historically religion has been part of shared collective memory and acted as a moral and symbolic object of attachment to a larger community (McGuire, 1997). Religious ideas and notion of ethics govern men's conduct, affect motivation and shape social action, which gives religion ethical and legitimating power (Weber, 1946).

Durkheim (1915) considers religion's main purpose to be integration of communities and societies. He set out to do two things, establish the fact that religion was not divinely or supernaturally inspired and was in fact a product of society, and he sought to identify the common things that religion placed an emphasis upon, as well as what effects those religious beliefs (the product of social life) had on the lives of all within a society. Durkheim's finding that religion was social can best be described by this excerpt from The Elementary Forms:

"The general conclusion of the book which the reader has before him is that religion is something eminently social. Religious representations are collective representations which express collective realities; the rites are a manner of acting which take rise in the midst of assembled groups and which are destined to excite, maintain, or recreate certain mental states in these groups. So if the categories are of religious origin, they ought to participate in this nature common to all religious facts; they should be social affairs and the product of collective thought. 
At least --for in the actual condition of our knowledge of these matters, one should be careful to avoid all radical and exclusive statements -- it is allowable to suppose that they are rich in social elements" (p.10).

Recognizing the social origin of religion, Durkheim (1915) argued that religion acted as a source of solidarity and identification for the individuals within a society. Religion provided a meaning for life, it provided authority figures, and most importantly for Durkheim, it reinforced the morals and social norms held collectively by all within a society. Far from dismissing religion as mere fantasy, Durkheim saw it as a critical part of the social system.

Religion provides social control, cohesion, and purpose for people lives, as well as another means of communication and ways of interaction that reaffirms social norms (McGuire, 1997). Religion is also a system of narrative metaphors that functions to answer questions about life (Herbert, 2003). As such it has both substantive and functional elements. It provides a narrative comprised of past memories and stories, myths and symbols; a narrative produced in interaction with others that guides identity development and social norms (Weber, 1946). Similarly, the grand narrative of one nation is a story of significant past events and historical memories loaded with values, ideas and beliefs. This is how, according to Anderson, the national identity- the unifying force of a large imagined community is generated (Anderson, 1991). The lasting power of religion, however, lies in its ability to address vital questions of human life such as death, disease, misery and loneliness (Durkheim, 1915).

The emergence of modern society was followed by development of nationalistic ideologies with all its symbols, beliefs and stories (Herbert, 2003). This means that the function of social integration that used to be performed by religion is now achieved by the ideology of nationalism that permeates state supported public institutions (McGuire, 1997). The expression 
of the cohesion of the nation is 'civil religion'. Civil religion is "any set of beliefs and rituals, related to the past, present and/or future of a people (nation) which are understood in some transcendental fashion" (McGuire, 1997, p.196). In former Yugoslavia, politics of nationalism and national identity caused thousands of people to willingly pick up arms and readily die for nationalistic cause (Ivanov, 1996). Moderate nationalism based on democratic liberal values is, according to Kymlicka (1998), necessary for the existence of the modern state. Taylor (1992) asserts that liberalism is a fighting creed among many others in a pluralistic society. Liberal democratic citizenship that is being promoted and installed in public schools is ideology based on myths, symbols and narratives (Seljak, 2005). The Ontario Alliance of Christian Schools $(\mathrm{OACS})^{2}$ claims that schools have become "civic church of Ontario, preaching the gospel of modernism that subtly homogenizes youth into the ethical and moral relativism of the modernist faith" (p.9).

Schools are therefore not a neutral public space where youth of different cultural and religious background meet and learn only the practicality of public reason. Rather, they are the sites of reproduction of dominant cultural ideologies (liberalism, capitalism, socialism, nationalism or religion) and power relations (McLaren, 1995). This has particular implications for religious minorities who are trying to preserve religious identity in the midst of wider secular culture (Zine, 2000, 2001). In Islam, religion is not simply instrumentalized and motivational force behind politics but it is an integral part of the way people make sense of their lives and face practical challenges and difficulties in life (Herbert, 2003). "Religion is not just a matter of how people cope with the problems of life but how they conceive of life, which in turn sets the stage from how they cope with it." (In Herbert, 2003, p. 26).

\footnotetext{
${ }^{2}$ Ontario Alliance of Christian Schools http://www.oacs.org/govrel/publications/PresentationPCJunc(05.pdf, Retrieved on August 10, 2006
} 
The revival of traditional religions and birth of new cults and movements may be reflection of how secular states have failed to provide safe and secure space for diverse religious communities (Zine, 2000). There are calls for new political philosophy that would allow religion into the public space with new policies of compromise that seek to accommodate religious practices of believers. How is liberal democracy, based on secularism of public space as the answer to pluralism of religions, to deal with the growing diversity of religious practices? 


\section{Secularization of educational public space}

A common argument against government support for separate religious schools is that such schools would encourage segregation of ethnic and religious minorities that will result in ethnic enclaves and divisions within society (D'Souza, 2000). In contrast, common educational institutions function to promote national values and democratic citizenship education that will unite people on the national level (Spinner-Halev, 2000). Secularists claim that only training offered in common public institutions that provide neutral ground, free of any religious convictions and traditional cultural values, can do this (Gokulsing, 2006). The principle of universality and neutrality translates into the political concept of secular public space free of religion. School system in North America is conceptualized as a public space where children from all backgrounds can come together and learn about each other not only through curriculum but also from each other and in the process confront others who are different which gives them the opportunity to learn values of co-operation, compromise and tolerance (Spiner-Halev, 2000). Children are also expected to shed their religious identities and "enter as equals in to the public space represented by the school" (Levinston, 1999, p. 123).

Secularization was constructed at the specific moment in history to transcend certain difficulties within Christendom and the Church's involvement with politics (Keane, 2000). Hence, secularization has come to be known as the separation of church and state (Daultazi, 2004). It implies that citizens should be free to believe or to worship according to their conscience; however, state must be neutral in its support for any one religion. In theory, such freedom allows for an open and tolerant civil society in which religion is privatized and plays little or no role in public spaces (Keane, 2000). Rawls's argument seems to suggest that the just state must be neutral in the midst of diverse religious convictions and perceptions of morality and open to reason that will unite all citizens in following the conventional concept of human 
rights (in Modood, 2000). The growing confidence that secularism and the decline of religiosity will give rise to more rational ways and open-minded tolerance is the product of Enlightment critique of religion (McGuire, 1997).

Secularization theory predicts that religion, due to modernization and its principles of industrialization, socialization, and rationalizations is to become a less important factor in social life (Herbert, 2003). The product of industrialization and development of large urban centers led to socialization i.e. the break up of small communities and the migration from rural to urban which resulted in diminishing significance of religion that served as a unifying power for these small communities. Large and complex societies, it has been argued, do not rely on shared beliefs for social cohesion but on impersonal rational systems that provide social integration (Herbert, 2003; Modood, 2000). Because commonality and conventional agreements are based on rationality, religion loses its influence in public life. However, it has not disappeared from neither public nor political realm (Peek, 2005; Bramadat, 2005). Although there has been a considerable decline in membership of organized religion, spiritual awakening has been a common trend in modern societies (D’Souza, 2000; Seljak, 2005).

\section{Rationalization of public space}

One aspect of modernization that led to secularization in public education is rationalization. Rationalization concerns the way people think and as a result the way they act (Herbert, 2003). It is based on practical reason, i.e. natural and physical phenomena are explained not by supernatural power but by scientific-rational worldview that provides "the technically efficient means of securing this-worldly ends" (Herbert, 2003, p. 40). 'Reasonabless', claims Callan (2000), is necessary for equal respect among individuals, fair treatment of others 
and acceptance of judgment. The practicality of instrumental reason has expanded across all subsystems of society: economical, political, legal and educational.

Due to modernization and industrialization new institutions were developed that replaced traditional community-based social systems (Herbert, 2003). Development of scientific study of human behavior, cognition and emotion led to increasingly rationalized public schools system dominated by secular, professional, technical, formalized and 'value-neutral' education (Cushman, 1995; Sikkink, 1990). The 'wall of separation' between secular and sacred, rational and traditional, individual and group and public and private was created. Conceptualized by small elite as a common place where children join together to learn the matter of public importance; as a site of reproduction of collective, universal discourse; as a vehicle for transformation of society by 'popular enlightment', schools inherited the most rigid characteristics of public space (Callan, 2000).

In modern democracies public space is characterized by 'public reason'. Habermas's definition of public sphere is a model of single public space in which matters of public significance and public interest can be discussed by members concerned with general social norms (in Herbert, 2003). In this narrow definition of public sphere standards are set by principles of public reason and therefore neutrality and practicality. This conceptualization of public space is evident in what Charles Taylor calls 'difference-blind liberalism' claiming that public space is 'a neutral ground on which people of all cultural background can meet and coexist' (Taylor, 1992, p.62). Liberal principles of secularism of the public space are based on practicality of public reason and neutrality that is believed to set the ground of universal principles that protects the rights and freedoms of all individuals. Holmes (1995) opposes such an authoritarian, monopolistic insistence on 'reasonableness' in public education that is "to be 
kept out of parents' hands and based on neither God nor mammon, but on Rawls", because it limits the freedom of choice for alternative educational institutions (p.2).

Fraser (1992) criticized such conceptualization of public space where "members of public sphere can somehow 'bracket' or leave behind their own cultural or status backgrounds when debating the public good" (Fraser, 1992; p.120). Furthermore, she argues that agenda included in the public space as well as public institutions that are culturally and ideologically embedded makes the public space more favorable of certain modes of expression and particular ways of knowing and thus more inclusive of some members of societies than others (Fraser, 1992). Squires (2002) talks of exclusions of oppressed groups, women, workers and peoples of color from the dominant public space, to argue for the necessity of multiple public spaces. Zine (2000) claims that Muslim student organizations in Ontario schools are developed as a site of 'formalized resistance' that allows Muslim students to "use their religious identities to challenge Eurocentrism in school policies, practices and curriculum" (p.293).

Rooney (2002) argues that classroom is neither public nor private space. It is rather a semiprivate space, where identities are formed, relations of authority established and discipline instilled. She proposes a semiprivate framework of commonplace that replaces contemporary discourse of opposing private/public components of civic life. Semiprivate is always a matter of negotiating locality and the boundaries, inclusion and exclusion and 'impersonal intimacy' (Rooney, 2002). Impersonal intimacy that develops between students and a teacher involves trust and is crucial for academic success of students. Dei (2001) claims that in African community teachers are perceived as an extension of family; such relationship among families and teachers enhances parental involvement in children's education. If schools are conceived as a strictly public space as in Habermas's view, alienation is inevitable, especially when parents perceive schools as hostile to their moral and spiritual values (Sikkink, 1999). By removing religion from 
public schools we are producing generations of religiously illiterate students not equipped with critical understanding of historical and political aspect of religions (Seljak, 2005). 


\section{Diversity in public schools: Historical perspective}

Establishment of Multiculturalism Act in 1988 has provoked public and academic discussion in regard to how much freedom ethnic minorities should be allowed in liberal democratic society such as Canada (Kymlicka, 1995). The new political climate of multiculturalism and politics of group recognition have stirred controversy and disagreement among political philosophers and academics on the special treatment of minority groups and the protection of cultural identities (Kymlicka, 1995, 2001; Taylor, 1992). Multiculturalism developed as a solution to the problem of minorities (Flearas \& Elliot, 2002) and has been the most criticized concept in the modern political thought (Kymlicka, 1998). The controversy of multiculturalism is that it means many things and yet it can mean nothing. Fleras and Elliot (2002) list a few possible definitions of multiculturalism: descriptive- an existence of diverse ethnic groups in the country; prescriptive-ideology that promotes diversity as normal and acceptable; political-government policies and programs to promote diversity; and practical-used by minority groups to protect their status and rights against majority. And while some suggest that multiculturalism served to engage diversity and protect minorities (Kymlicka, 1998; 2001); others argued that it divided Canadians by keeping minorities in subordinate place (Bissoondath, 1994); yet some people claim that multiculturalism has been used to promote the dominant agenda and cover up more important issues of racism and discrimination (Bannerji, 2000). Multiculturalism in education is no less controversial. Harper (1997) identifies five responses to diversity in public education: suppressing difference or assimilation, insisting on differences, denying differences, inviting differences and critiquing differences (p. 192). At the turn of 20th century, carefully regulated education, enforcing Anglo-Saxon culture, English language and Christian morality, was designed to erase differences and ensure common 'Canadian identity' (Harper, 1997). First Nations peoples were to be civilized and their souls 
saved by submerging their children into European culture, religion, customs and language (Moodley, 1995). Because of such aggressive assimilation practices in education, French in Ontario had to struggle to establish separate Roman Catholic schools that would teach and help maintain French language (Trebilcock \& Kelley, 1998). Historically, education has been a vehicle to promote national unity through ideas of liberalism, nationalism, capitalism and "common Christianity rooted in the general system of truth and morals" (p. 181).

Insisting on diversity followed the ideology that differences are natural, predetermined and biological and therefore could not be eliminated (Harper, 1997). This led to development of separated and distinct education of Blacks, women and disabled based on assumption that particular identities (gendered, racial etc.) predetermine social role and social status (Harper, 1997). Segregated Black schools are still a controversial issue in a contemporary postcolonial discourse in which Afrocentric schools are considered to be a point of reference for interrogation of power structure in society and site of resistance to dominant hegemony (Dei, 1996, 2000). I will return to this point in discussing alternatives to multicultural education.

After the World War II humanist-liberal notion of the individual and the equality as well as the scientific doubt that differences are innate brought about discussions of equity, access and anti-discriminatory practices in public schools (Harper, 1997). Denial of differences and insistence on color-blindness in the midst of oppression of Blacks and suppression of women was a political statement that did not improve the condition of marginalized groups (hooks, 1994). By working from this framework schools lacked the power to raise the consciousness about powerful, mainstream hegemony, thus leading to schools' practices and policies that completely undermined the political and social position of those who were visibly different (Friere, 1978). hooks (1994) argues that denying differences helped sustain power hierarchies by failing to respond to the need of racial minority groups. Political theorists have argued that 
recognition of diversity is first and foremost the matter of justice, equality, equal distribution of goods and equal participation of all members in pluralistic societies. Fraser (1992), for example, treats recognition as a question of social status. To view recognition as a matter of status is "to examine institutionalized patterns of cultural value for their effects on the relative standing of social actors" (Fraser, 1992, p. 24). According to this model, misrecognition occurs when institutional structure based on particular cultural norms hinder equality of participation (Fraser, 1992).

Development of multicultural policy acknowledged diversity and cultural pluralism as fundamental to Canadian identity (Kymlicka, 1998). Consequently schools developed programs and policies centered on multi-cultural education "to ensure that all children be given the opportunity not only to develop and retain an identity informed by the historical roots of their culture and community but also to understand and appreciate other ethnic and cultural groups" (Harper, 1997, p.6). Although multicultural program initiatives in education have generally been highly valued many people criticized the folkloric version of multicultural education as it reinforced the cultural stereotypes and concealed issues of more significant concern such as racism and other forms of discrimination (McLaren, 1995; Fleras \& Elliot, 2002). Because education is provincial responsibility-unlike multiculturalism- multicultural practices differ from province to province (Moodley, 1995). Moreover, implementation of policies was the responsibility of school boards and depended on individual teachers and administrators who were never adequately prepared to deal with issues of multiculturalism in classrooms (Moodley, 1995). More recently the argument for public funding of independent religious schools turned into the language of multicultural debate and the issue of recognition of cultural identity and protection of group survival that calls for special treatment of minority groups rather than equity for all (Scott, 1999). 


\section{Current policies of accommodation in multicultural education}

In response to demand of ethnic groups for more religious accommodation in public schools Ontario Ministry of Education published a document called "Opening and closing exercise for public schools, $1993^{\prime \prime}$. The document aimed at making public schools more open to diversity of religious beliefs. Opening and closing exercises have a few purposes. One is educational and the other is patriotic. The educational purpose is to encourage social, moral and spiritual growth of children by recognizing that 'no one institution has an exclusive responsibility in this regard' (p.3). The document states that although developing values in children is seen as a primary responsibility of parents and religious organizations, schools do have a clear responsibility to help children reflect on and develop the sense of universal human values essential for the well being of the individual and society. Exercises approved under this document are aimed at developing understanding of shared values and acceptance of different cultural ideologies by including important historical, cultural and religious narratives. Opening and closing exercises also have a purpose in promoting the Canadian vision of a humane society based on justice, human rights, equal opportunities, freedom and democracy.

Ontario regulation 298, section 4 on opening and closing exercises consist of 5 points, the first of which is that every public elementary and secondary school shall hold opening or closing exercises. The readings must endorse the principles in the Ontario Human Rights Code and the Canadian Charter of Rights and Freedoms. Readings are selected in consultation with religious communities and focused on ten themes: "respect and care for others, commitment to honesty, equity and justice, respect and care for self, commitment to non-violent problem solving, respect an care for the environment, pride in Canada-its heritage, diversity and ideals,

\footnotetext{
3 'Opening and closing exercise for public schools', Ontario Ministry of Education, Retrieved August 01, 2006 from http://www.edu.gov.on.ca/eng/document/resource/ecu93105.pdf
} 
sense of community, appreciation of the human spirit in its capacity for wonder, joy and love, appreciation of learning as a lifelong process and sense of transcendence" (p. 23). In addition to 'O Canada', opening exercises should have two or three more components one of which should be the chosen reading and another the period of silence.

In introducing the period of silence, teachers should avoid prescribing how this period is to be used but rather allow students to independently determine suitable activities such as personal reflection or silent prayer (p.15). The document also offers a number of diverse secular and religious readings for each of the themes discussed above. This educational policy aimed at accommodating religious minorities clearly suggests that: a) educational institutions are responsible for development of spiritual growth of children, b) different cultural ideologies need to be incorporated into curriculum, c) that religion have a positive contribution to make in developing of a tolerant and peaceful society.

The policy on opening and closing exercise is incorporated into the larger document found on the TDSB (Toronto District Schools Board) web site called 'Guidelines and Procedures for accommodation of religious requirements, practices and observances ${ }^{34}$. The Board is committed to the implementation of educational policies, the accommodation for religious practices protected by the Policy and to the removal of any discriminatory practices. Under this document the areas of accommodation include: "observation of major religious holy days and celebrations, school opening or closing exercises, prayers, dietary requirements, fasting, religious attire, modesty requirements in Physical Education, participation in daily activities and curriculum" (TDSB, 2000, p.6).

Under section 304 of the Safe Schools Act, 2000, boards are required to ensure that

\footnotetext{
4 TDSB, Guidelines and Procedures for the accommodation of religious requirements, practices, and observances. Retrieved March 27, 2006, from www.tdsb.on.ca
} 
opening and closing exercises are held in all of their schools. Students can be exempt from the participating in opening or closing exercises under the circumstances set out in the regulations. Unfortunately, neither this document nor the web site of TDSB offer more information about the ways in which the Board ensures that individual schools incorporate opening or closing exercises. Although two policies discussed here have different focus both are attempting to make public education more inclusive for immigrants and cultural minorities. The first document (Opening and Closing Exercises, 1993) is focused on how to make curriculum more accepting of other views and beliefs, while second (TDSB, 2000) is concerned more with making space for other cultures and values within the school structure.

Despite the very elaborate and well-intentioned policies to accommodate religious practices and beliefs their implementation is inconsistent and it does not address the issues of discrimination, marginalization and exclusion (Zine, 2006). Seljak (2005) argues that although public schools have moved forward in accommodating religious diversity it does so in a highly superficial and 'celebratory' way. Education continues to be fundamentally secular and does not make room for alternative worldviews. Children lack the understanding of religious diversity and the ability to use traditional wisdom and indigenous knowledge to reflect on their knowledge and to re-invent the social boundaries. 


\section{Criticism of current practices in multicultural education}

The effort of Ontario Ministry of Education and Toronto School Board to recognize concerns of religious minorities in public schools was not likely to satisfy demands of traditionally minded religious groups. For example, Muslim parents who are committed to maintaining religious identity were troubled with 'the secular liberal character of contemporary public education' (Azmi, 2001, p.263). Not only was the issue of gender roles and gender relation of concern for Muslim parents but also the pressure to conform to and experience the lifestyle common for youth in secular public schools such as dating, premarital sex and alcohol and drug use (Zine, 2001). Although intended to promote inclusion, the implementation of equity policies are left to the discretion of school boards, school principals or individual teachers who often complain about the lack of resources. Terms of accommodation served to further strengthen the boundaries of marginalization and alienation of children trying to negotiate their religious identity within the secular educational culture and curriculum structure (Dei, 1964). Liberal values promoted in educational institutions speak of Euro-centric attitudes towards the recognition of other cultural identities (Azmi, 2001).

Folkloric approach to cultural recognition in multicultural education and 'equity' insisting policies deny the systematic marginalization of racialzed and religious minorities. Multicultural education has come under severe attacks in academic circles for perpetuating status quo and serving as a tool of eventual assimilation of ethnic minorities into Anglo-Saxon culture and ideology (Fleras \& Elliot, 2002). Difference blind liberal approach to education has created the climate of center-margin divisions whereby Euro-centric, postcolonial, white ideology is positioned at the center and 'the Other' on the margins (Dei, 2000). 
To understand the struggle of religious minorities to escape the marginalized space and position themselves in the center of political discourse we need to interrogate the practices of multicultural education. Research studies have identified a number of discriminatory practices in contemporary education:

1. Lack of reflection of racialized and religious identities in schools' administration and structure (Dei, 1994; Zine, 2000, 2002);

2. Teachers' negative perceptions and attitudes towards students of ethnic background and lack of recognition of cultural capital that students bring to schools (Howard, 2003; Kilbride, 2000);

3. Peer pressure to confirm to mainstream culture that leads to family conflict (Tyyska, 2006; Zine, 2000).

4. Attitudes of xenophobia, Islamophobia and racism translate into the systematic forms of oppression (Zine, 2003, 2006).

5. Curriculum that neglects histories, traditions, cultures, language and contributions of peoples other than Europeans to world knowledge presents an obstacle for youth to understand, reflect and develop positive cultural identities (Ladson-Billings, 1995; hooks, 1994).

\section{Administration and school structure}

Exclusion of racial and religious identities from the structure of public schools is evident on two levels. First, there is a lack of representation of black population in the school administration; teachers are still predominantly white and female (McLaren, 1995). Many scholars have noted that absence of Black teachers negatively affects the motivation of students to excel because they have no role models in school (Dei, 1996, 2000, hooks, 1994). Absence of 
teachers of color reinforces the marginalized experience of racialized minorities and negative resistance because students do not necessarily identify with teachers' lived experience. In one study students talked about demoralizing effect that absence of black teachers had on them (Dei, 1996). Racialized students' negative experience with white teachers included: misunderstanding of cultural capital, formality in the relationship, lack of trust and understanding of marginalized experience (Ibrahim, 2000). Teachers' perceptions and attitudes, not only their strategy in teachings are important factors in students' academic success. Three factors are identified in literature that teachers must provide to protect high-risk students from failing: caring and supportive relationship, high expectations, and opportunities for meaningful participation (Kilbride, 2000).

In addition to lacking representatives of different racial and cultural background in administration, schools often have difficulties accommodating religious minorities with room for prayers, time for prayers, and exemption from classes to accommodate religious holidays (Zine, 2000). Because religious accommodation is left to the discretion of schools board and school administration Muslim students struggle with the system to recognize their religious practices and needs (Azmi, 2001). A board-based equity policy does not address the distinct needs of each community in public because some community needs might have higher needs than others, for example oppressed groups might need more resources and support to escape the marginalized space (Zine, 2000). One example of this would be Black community and affirmative action. The Multifaith Group for Equity in Education, based in Ontario, that demands public funding for alternative schools, argues that equity in education should start with equitable distribution of public education tax dollars (Azmi, 2001). 


\section{Teachers' perception and attitudes}

Teachers' negative perceptions and attitudes towards students of different ethnic background is the most salient form of discrimination. Religious identification adds to the visibility of 'otherness' among racial, gendered or class dimension of identity that situates students outside the margins of 'normalcy'. Negative stereotypes and attitudes towards racialized and religious minorities are often referred to as 'deep curriculum' (Dei, 1994, Zine, 2006). In addition to school rules, regulations and structure, 'deep' or 'hidden curriculum' includes school's culture that is reflected in activities, behaviors, perceptions and expectations of administrators, teachers and students (Seljak, 2005). Muslim girls who wear hijab (the head covering) often report feelings of alienation caused by negative perception and misconception of some teachers whose image of 'repressed Muslim women' guided their evaluation and assessment (Zine, 2006). Negative attitudes and assumptions that teachers hold towards minority students can affect their self-image and translate into a self-fulfilling prophesy that further disempowers them (hooks, 1994). Studies have shown that academic streaming negatively affects ethnic minorities as they are channeled to the lower academic streams (Dei, 1995). Bernhard (1990) argues that ethnic children are often sent to special classes because they lack English language skills, cultural capital and parents' inability to advocate for their children.

Teachers need to understand that students come to the class with cultural capital that is not often easily translated into that of the mainstream culture (Howard, 2003). Human, social and cultural capital are closely connected although each refers to a different type of capital, each likely to enhance children's chances of success in a different way (Kilbride, 2000). In addition to skills and knowledge, human capital also includes motivation, expectations and styles of interaction that position individual in the relation with others. Social capital is used to refer to the network of friends, family and people in a community who can provide resources of knowledge 
and connections that lead to other forms of capital. Social capital has been identified as important factor for enhancing achievement (Kilbride, 2000). Cultural capital is defined as norms, values, beliefs, cultural practices, behaviors, language, information, understanding, skills and ways of engaging in particular practices (Rueda, Monzó \& Arzubiaga, 2003; Howard, 2003). Religion provides norms and values that guide cultural practices and peoples' behavior. It is integrated in language and informs the way of knowing about the world and one's self in relation to others (Peek, 2005). As such it needs to be recognized as a part of cultural capital and the point of reference for students whose family life revolves around religious practices and beliefs.

Teachers' failure to recognize human or social capital of religiously motivated students can lead to further alienation and marginality (Sikkink, 1999).

In the study "Teacher experiences of culture in the curriculum", Chan (2006) examined the challenges teachers face in recognizing different sources and types of students' capital and acknowledging their ethnic, linguistic and religious diversity. Despite a great number of research studies and discussion on acknowledging diversity in classrooms there is little consensus on what is the best way to deal with issues that are in conflict with liberal position of teachers (Fleras \& Elliot, 2002). Chan (2006) describes a case that represents distinctiveness in beliefs and values of children and their families, from those of teachers in a Toronto school and shows the lack of teachers' knowledge and sensitivity to cultural differences. The school organized a 4-day field trip as a learning activity beyond classroom. One Muslim girl could not go because it was against her family's religious beliefs. When the teacher offered to talk to her father the girl explained that it was not appropriate for her to attend such activities. The teacher in the interview expressed difficulty to understand and morally support religious practices that are against his liberal beliefs concerning gender relations and learning activities (Chan, 2006). The reverse is also true, 
religious parents have difficulty supporting some liberal practices in public education and therefore choose alternative schools.

\section{Peer pressure}

Peer pressure to assimilate into the mainstream culture is the most challenging problem minority students' face in public education. Zine (2000) in her research talks about Muslim students who were able to resist peer pressure to date, use alcohol or drugs, or attend pubs, bars and clubs through social networks and organization developed by Muslim students in public schools. Peer pressure to conform to the values and activities of dominant group creates conflict within the families as parents try to exert greater control over their children limiting their activities and social events. Tyyskä (2006) writes about intergenerational conflict and instability that occur in the Tamil families because children are trying to 'fit in' at school. This leads to deterioration of families, negative perception of cultural values and youth violence (Tyyskä, 2006). Other studies also show that second-generation immigrant youth in their effort to be accepted by the majority often reject their ethnic identity and religion, but as they experience barriers and marginalization many attempt to reclaim their ethnicity by constructing highly defensive forms of ethnic identity (Chong, 1998). Therefore, it is not surprising that second generation immigrants become more religiously and culturally involved, reclaiming sometimes in extreme ways what their parents might have left behind their countries of origin.

Minority students develop network in schools that provide familiar environment supportive of their cultural or religious identities. Muslim organizations within public schools offer social networks and collective form of resisting forces of assimilation. "Creating systems of positive peer support was viewed through the narratives as essential to the maintenance of an Islamic identity and lifestyle" (Zine, 2000, p.306). They act as a subculture within the public system that offers an alternative to functions like school dance or sporting activities that are 
based on Islamic principles and rules. Liberalist who worry about segregation of children from the same ethnic or religious background in separate schools forget that such segregation happens voluntarily in public schools as a form of resisting assimilation to the mainstream culture.

\section{Xenophobia, Islamophobia and Racism}

Xenophobia is present not only in attitudes of children and teachers but also in the ideology of secular public education (Zine, 2006). Historically xenophobia has affected different groups at different times. Chinese, Italians, Ukrainians, Blacks were all at one time victims of xenophobic attitudes (Kelly \& Trebilcock, 1998). In recent history, world events and negative perceptions and stereotypes of Muslims in popular media led to Islamophobia defined as "a fear or hatred of Islam and its adherents that translates into individual, ideological and systemic forms of oppression and discrimination" (Zine, 2006, 239). In 1975, the Canadian Society of Muslims based in Toronto, produced a document titled 'On the image of Islam in school textbooks in the Province of Ontario' that was submitted to Ontario Ministry of Education, calling for elimination of 11 text books approved for study in Ontario that portrayed Muslims in a negative and stereotypical manner. Eventually only 7 out of 11 books were eliminated (Azmi, 2001). Today, Muslim students who take world religions courses in public schools report bias in the curriculum and teachers' lack of proficient knowledge about Islam (Zine, 2000). In the wake of the world events Islamophobia is stronger today than ever before. For Muslims girls who adhere to dress code of Islam, the identification of their faith with terrorism and the consequent oppression and marginalization can lead to psychological and emotional suffering (Al-Jabri, 1995). Researchers have noted distinctiveness in attitudes towards Christian schools that are generally more accepted and Islamic schools that are perceived as 'a threat, or breeding ground for terrorism' (Seljak, 2005). 
The rejection of Muslim cultural identity within the school structure due to the attitudes and perceptions of teachers, peer-pressure and Isalmophobia, will not promote tolerance. Rather it will lead to minorities' resistance that can turn into a very strong and rigid ethnic and religious identification (Chong, 1998). Zine (2001) argues that because of this difficult socio-political context of identity negotiations "Islamic schools continue to be safe havens where these girls find freedom from racialized and Islamophobic stereotypes" (p.239).

\section{Curriculum}

Curriculum based on one particular way of knowing, European, rational, universal etc., undermines cultural capital and cultural knowledge as an important frame of reference "within which students can connect socially, politically, ideologically, spiritually and emotionally to the learning process" (Dei, 1996, p. 6). Curriculum can be defined as "the organized environment for learning in a classroom and school; as such, it is never neutral but represents what is thought to be important and necessary knowledge by those who are dominant in a society" (Murtadha, 1995, p.354). Through curriculum schools participate in re-shaping students' cultural identity and perpetuating the existence of power relations by using the language of objectivity and universality of human reality as constructed by categories of race, class and gender (hooks, 1994). Under the spell of preparing students for the individualistic consumer society, believed to promote diversity, contemporary educational practices fail to address historical development of white privilege through imperialism, colonialism and capitalism (Dei, 1994; Giroux, 2003). Multicultural education is fundamentally problematic as it inherited the center-margin, us-them ideology of Eurocentricity and postcolonial discourse of nation building without questioning the power relations of this duality (Dei, 1996, 2000). White supremacy is subtly present in curriculum overwhelmed with history, literature, science and social ideas all written from the 
position of postcolonial framework (McLaren, 1995). Similarly by removing religion from the curriculum children of different religious backgrounds lose the opportunity to learn about their social and cultural identities of which religion is an important part.

\section{Politics of multicultural education}

Multicultural education does not address the inequalities embedded in social structure where different is still considered deficient and rejected as such (Bedard, 2000). Liberal multiculturalism recognizes cultural differences but positions them in the hierarchical order and overshadows them by insisting on individual self-development where agency and choice appear to be independent of collective and as such highly valued (Zine, 2000). By disconnecting individual from public space and social responsibility social problems become individualized and "translated into failure, laziness, bad luck or simply indifference" (Giroux, 2003, p.8). Under the neoliberal framework, present in the theory of liberal multiculturalism, communities are privatized, cultures are to be consumed, and democracy is based on profit and private interest. Schools have become the sites of production of obedient workers and capitalist social relation that legitimized domination of ruling groups (Murtadha, 1995). Consequently, schools have been unsuccessful in mobilizing subordinate groups to move from their marginalized position to the center (Giroux \& McLaren, 1992). McLaren (1995) argues that "multiculturalism without a transformative political agenda can just be another form of accommodation to the larger social order."(p. 42). Because of its emphasis on 'equity for all' and universality of values, liberal multiculturalism that is entrenched in public schools, often leads to Anglo-centrism and assimilation. 


\section{Critical theory, critical pedagogy and culturally relevant teaching}

Critical theory (Freire, 1978) that translates into the critical pedagogy (Chen, 2005) and culturally relevant teaching (Ladson-Billings, 1995) present an alternative approach to education that situate cultural, racial and religious identities at the centre of educational practice. The language of critical theory is concerned with issues of equality, social justice and the well being of humanity. Freire (1978) argues that resistance in form of violence against the unjust system and the power relations in society that position racialized groups as less worthy and subordinate only further dehumanizes them. Authoritative attitude of teachers, who are mostly white, female and middle class, disengages students from participatory learning (hooks, 1994). The practice in most public schools is that teacher plays a role of the instructor, the one who possesses the knowledge and whose job is to pass on the knowledge based on Eurocentric history and dominant hegemony while omitting and devaluating stories and histories of other groups (Dei, 1996). "The white, Eurocentric, secular cultural codes of Canadian society are the standards of measure against which all other identities are judged and positioned, and within which all other identities must be disciplined into conformity or face exclusion" (Zine, 2006, p.246).

According to critical theory knowledge in schools should not be seen as absolute or neutral but rather as subjective and constructed by dominant groups to secure their power and dominance (Friere, 1978). In contrast to current multicultural approach to education whereby common culture (liberal) and sameness of identity is emphasized and diversity celebrated; critical pedagogy, based on critical theory, study individual as the agency acting within structural context that is constrained and defined by that context and thus recognizes that cultural identity is closely related to power relations because of the group membership (Chen, 2005). 


\section{Language of the critical pedagogy}

Culturally relevant pedagogy has been described by a number of researchers as an effective means of meeting the academic and social needs of culturally diverse students (Howard, 2003). Culturally relevant pedagogy uses the cultural knowledge, past experiences and learning styles of students to make learning more connected to their lived experience and more effective for them (Ladson-Billings, 1994). This means that schools have to adapt to cultural experiences, knowledge, language and mode of being in order to empower students and effect social change.

Language is crucial factor in development of cultural identity. It is used as a tool in construction of self as well as the construct of self (Mead, 1934). Many educators use anti-racist framework as an anti-oppressive discourse to criticize multicultural pedagogies for not scrutinizing and analyzing the language of dominance because it is through language that humans actively construct and reconstruct their identities (Ibrahim, 2000). In an effort to keep education neutral, objective and universal multiculturalism is unable to move from the wellintentioned and elaborated theory to a new vision of schooling that recognizes the way language is used in the politics of recognition. Giroux \& McLaren (1992) argue that 'the purpose of a critical language of schooling is not to describe the world more objectively but to create a more ethically empowering world which encourages a greater awareness of the way in which power can be mobilized for the purpose of human liberation" (p.3). Education must scrutinize the language of 'secularism' that in dominant discourse means exclusion of religion from public space but in Arabic language it has been initially translated as 'dahriyin', a Qur'anic term used to describe atheists and their attack on Islam (Keane, 2000). Although the term secularism for Muslims has come to mean simply non-religious, deep-seated antagonism and judgment embedded in the dominant language towards 'the other' is often left unquestioned. Academia is 
often criticized for being the keeper of the power because it regards and accepts only particular language and particular understanding as knowledge that is often disconnected from the lived experience of students. Gorge Dei (1996) acknowledges that in order to engage a discussion about inclusiveness of Afrocentric way of knowing he must use the language of "those who historically and currently hold positions of dominance in society" (p. 2).

However, using the language of dominant groups through which politics of representation are outplayed, oppressed groups are adopting their subordinate position, internalizing it as the only way of being. (Giroux, 2003).Only when students are given the language they can relate to will they be able to give voice to their own experiences and affirm themselves as the active social agents in the struggle for social justice (Giroux, 2003). The language of religion is different from the language of secularism and rationalism. Children bringing to school language of their homes that happens to be religious rather than secular are ignored and their voices are silenced (Zine, 2000). In order to accept, challenge, reflect on and consciously choose their social identities children must first develop one that is not demonized and marginalized. 


\section{An alternative: Anti-racist (anti-oppressive) education}

Current educational policies and practices developed around ideas of color-blindness, equality, neutrality and universality have failed to recognize and interrogate power differential based on religious, cultural or racial differences. How do we as educators, policy makers and advocates encourage social change if the school's structure is excluding some groups; if teachers are not prepared to take differences seriously and if the negative perceptions and misrecognition of children's cultural capital continues to dominate their teaching style? How do we fight racism and xenophobia in society if education is denying it? How do we escape the seductiveness of rhetoric of equal treatment, equal opportunities and universality, and start questioning the power hierarchies in politics of identity?

Anti-racist framework offers a new paradigm for political and social change in education. It works towards the development of positive cultural identity by positioning marginalized groups into the centre of classroom pedagogy (Murtadha, 1995). The main objective of antiracist discourse is to provide more opportunities for an alternative ways of knowing that are free from Eurocentric norms and conceptualizations (Dei, 2005). It takes holistic approach to human conditions rejecting mind-body dualism as much as critical theory rejects the reductionism from the cultural, social and situated human activities to individualistic centered behaviorism. Carr \& Klassen (1997) state that "the aim of antiracist education is to change institutional structures, validate the lived experience of an increasingly student body, and alter inequitable power relations" (p. 67). In contrast to multicultural framework, anti-racism is political and situated knowledge that questions the position of both privileged and marginalized. Its transformative knowledge creates awareness and critical consciousness for social change by scrutinizing power relations from the perspective of institutionalized privilege (Carr \& Klassen, 1997; Dei, 2005). In anti-racist discourse on education identity is situated in a broader social and political context of 
inequalities. Multicultural education by insisting on 'equality for all' serves to cover the privileged position of dominant group by trivializing racial, religious, gendered and class differences (Zine, 2001; Dei, 2000). Anti-racist framework recognizes the multiplicity of position that each individual occupies and therefore attempts to move beyond the dualistic ideology of white/ black and center/ margin by focusing on the relational aspect of categorization (Ibrahim, 2000).

The main goal of anti-racist praxis is centralization of the historically marginalized groups (Bedard, 2000). Separate Afrocentric schools are a good example how independent schools might be able to remedy discrimination practices and marginalized experience of minority children in public education. The focus of Afrocentric schools is a research and discourse based on perspectives of African people, their epistemologies, philosophies, spirituality and ways of knowing and dealing with physical and social world (Dei, 2005). This type of knowledge would allow students to be active participants in construction of the knowledge that is connected to their marginalized experience, whatever that marginalized space might be racial, gendered, religious and class. Connected learning is the most effective way of engaging children with curriculum (Friere, 1978). Critical pedagogy emphasizes that student resistance to institutionalized education lies in disconnect and contradictions between their lives and what is being thought in the dominant discourse (Freire, 1973).

According to Abarry (1990), Afrocentric education is characterized by the following ideas: the sense of self is culturally situated, therefore, human beings are conceived collective or extended; human beings are connected to universe and responsible for one another; recognition of goodness in oneself and the others; the knowledge is subjective and relative and the highest value is placed on interpersonal relations. It is evident that in contrary to current Eurocentric individualistic and consumerist self, Afrocentric curriculum is centered on teaching values that 
promote social responsibility, collective self and development of social context for just and balanced community. "African world view contains within it the social and ethical value of social well being, solidarity, interdependence, cooperation and reciprocal obligations-all of which can contribute to equitable distribution of resources and benefits to society." (Murtadha, 1995, p.357). Afro-centric education is culturally and spiritually focused (Dei, 2005). It presents one alternative to secular, rationalized and technical educational program of contemporary North American public education. Similarly, religious schools focus on moral and ethical values of social being: justice, forgiveness, solidarity, commitment, social responsibility (Bramadat, 2005). The importance of inclusion of history written from the marginal experience, spirituality, collective memory and different ways of knowing in education is critical for social change (Dei, 2000). Colonizing discourse of sameness that still permeates our educational practices reflects the mentality of teachers who claim that there is no racism or other form of discrimination in education. Meanwhile systemic discrimination and historical oppression of minority groups are left unquestioned. Freire (1973) remind us that education is never neutral as it serves to either "perpetuate the status quo or it helps students become conscious agents and active participants in the creation and transformation of the society" (p. 15). Knowledge is political and schools as the site of knowledge production is a political institutions and as such must always interrogate its political stand. Religion as a social force must be a part of this interrogation. 


\section{Discussion}

Recognition of religious groups in public schools is a very complex issue in political, ideological and practical sense. In this paper I focused on few ideological themes found in the literature on public support for religious schools. Starting with different views on identity, I attempted to show that Western ideas of identity as a masterful, isolated self are reflected in our educational system that is still very Eurocentric. On the contrary, post modern perception of identity found in theories of social construction and symbolic interactionism (Mead, 1934; Hermans, 2003; Cushman, 1995) are reminiscent of Eastern view of collective self. Later approach is reflected in critical theory and culturally relevant teaching (Friere, 1978; LadsonBillings, 1995) that interrogate political standpoint of public education.

Secularization of public educational space is another sign of Eurocentric worldview that confines an important part of social identity to the private space of home. For religious minorities, the fundamental element of their personal and group identity is ignored and denied by the society. Revival of religion around the globe is largely a result of many years of compressing religion into the private space and 'dealing with it only when it noisily intrudes into our public sphere" (Seljak, 2003, p. 71).

According to Squires (2002) "the move away from the ideal of a single public sphere is important in that it allows recognition of the public struggles and political innovations of marginalized groups outside traditional or state-sanctioned public spaces and mainstream discourses dominated by white bourgeois males" (p. 446). Oppressed and marginalized groups have traditionally resisted dominant power by occupying counterpublic sphere. Counterpublic sphere emerges as a response to exclusionary practices of dominant group (Squires, 2002). It becomes the site of resistance and a safe space for marginalized groups to oppose and challenge dominant hegemony. Student subcultures, as defined by Zine (2000) have the characteristics of 
counterpublic sphere. The social organization of Muslim youth in schools is a form of Islamic subculture based on suppressed forms of religious identification that "utilize, to varying extents, the politics of resistance to counteract their marginality and subordination as a religious minority in a secular schools system" (Zine, 2000, p. 297). Squires (2002) warns us about counterpublic spheres that become distanced from the public sphere "due to oppression they might want to selfsegregate and become independent of other publics in order to maintain group identity and retain sense of superiority" (p.464). She also asserts that all spheres are fluid and whether a counterpublic sphere becomes a satellite depends on dominant public ability to engage oppressed group in the dialogue.

The current multicultural educational practices reflect a single public sphere characterized by Eurocentric worldview with number of counterpublic spheres occupied by religious and racialized minorities. Disengagement of separate religious schools from public space is a sign of our unwillingness to create multiple spaces within the public sphere that would serve as space of equal and positive contribution in the social change rather then a 'counterspace' of marginalized resistance. Dei (1996) argues that unless we create multi-centric space in education, Afrocentric, Eurocentric, Asiacentric (or Islamcentric) and develop 'pedagogy of the home' we will not have a truly inclusive education that allows for re-invention of these important ways of understanding the world. For religious minorities de-centering of education would mean allowing their lived experience to inform the way knowledge is constructed. If a particular way of knowing is removed from the marginalized space in which it is regarded as inferior, irrational or subordinate and placed in the center of public discourse, it will allow for critical reflection and interrogation of the validity or practicality of that knowledge (Dei, 2000). In the marginalized space such knowledge creates a space of resistance rather than a space of equal contribution and growth of society. Although equality can be constructed in different ways, for some it means 'an 
undifferentiated notion of sameness' and for others it means different but equal, the fact that individuals and their agendas are mobilized and given voice through their associations and groups must not be forgotten (Zine, 2001).

Multi-centric approach to education, as proposed in anti-racists framework translates into the multiplicity of public spheres that are not exclusive of any other, but based on distinctive way of being in the world. These centers are not fixed by religion or ethnicity or any other social identifier; they rather present a point of reference, a safe place for interaction with others and self-reflection. The boundaries of multiple public spheres will transform as the political agenda changes. Public funding for separate schools would create a space for critical reflection beyond classrooms that will in turn allow for further self-transformation of secular as well as religious schools. The real, meaningful transformation of public education must come from top-down approach; therefore, multiple public spheres would create a multiple educational perspectives. Multiple public spheres would reflect a true multicultural society where people can freely move into different spaces according to their group identification or political agenda. Systemic oppression in public institutions can only be challenged by creating alternative spaces.

Public funding for religious schools is one way of reintegrating them into the public space. It will ensure quality of services and programs in religious schools, appropriate salary for qualified teachers, new programs and equipment, and help develop more extra-curriculum activities that are not necessarily religiously based. Furthermore, choice of schools would not be limited only to those who can afford it. Public support for religious schools will ensure that no school is left behind. 


\section{Conclusion}

"Am I suggesting that, if we hope to create truly civil society, we must first burn all the flags and kill all the gods, because in such a world we could no longer tolerate such weapons of mass destruction?"

Thomas King

School is a microcosm of society, a bridge between a family and a community, and as such it ought to be a place where families and society join together in making of the future generations. Therefore, schools are shared responsibility of the families that make community, and the government. Contemporary accommodation practices and equity policies in education have fully satisfied many religiously oriented minorities who send their children to public schools. However, for others who wish to educate their children in the light of their traditional values and religious beliefs, narrowly defined religious needs in education policies are perceived as discriminatory and stereotypical

Aboriginal peoples still suffer the consequences of having had European values and views imposed on them. Today Canada has become a home to more than just two European ethnic groups, yet Eurocentric public space is still prevalent. Muslim, Jewish, Protestant and other private schools already exist; with the funding from the government financial burden will be taken off parents, discrimination of non-Christian groups stopped and some kind of government regulation established. It is past due that Ontario government follows the example of other provinces and allocates money for other religiously based schools as it has been doing for decades for Roman Catholics.

Learning about world religions is important, but before children explore the world through books they should learn about the ideology they identify with. Learning about Shakespeare, French Revolution and Social Darwinism is important, but studying Qur'an and 
Muslim writers is crucial for making space that allows for meaningful participation through connected learning.

Having lived in post-communist Yugoslavia most of my life, I experienced strictly secular society turning into religiously conscious communities making religiously based political decisions. A sleeping dragon of Balkans, religion, had been woken up and used for political interest that resulted in one of the worst religious conflict in modern Europe. The communists' decision to 'kill all the gods' in the name of equality and 'sameness' did not prove to be a lasting solution. Therefore, we need to understand what role gods and flags play in the 'imagined communities' and to constantly negotiate the horizons of knowledge that any ideology we choose to live by, establishes. 


\section{Reference:}

Abbary, A. S. (1990). Afrocentricity. Journal of Black Studies, 2.

Al-Jabri, H. (1995). Doubleyouth, the split personality syndrome, The Message, 20, 28.

Anderson, B. (1991). Imagined communities: Reflections on the origin and spread of nationalism. London: Verso.

Azmi, S. (2001). Muslim Educational Institutions in Toronto, Canada. Journal of Muslim Minority Affairs 21(2).

Bannerji, H. (2000). The paradox of diversity: The construction of a multicultural Canada and "women of colour" (Chp.). In The dark side of the nation. Essays on Multiculturalism, Nationalism and Gender. Toronto: Canadian Scholars Press.

Baumeister, R.F. \& Muraven, M (1996). Identity as adaptation to social, cultural and historical context. Journal of Adolescence, 19, 405-416.

Bedard, G. (2000). Deconsturcting Whiteness: Pedagogical Implications for Anti-Racism Education. In G. S. Dei \& A. Calliste (Eds), Power, Knowledge and anti-racism education (pp. 41-49). Halifax: Fernwood Publishing.

Bernhard, J. (1990). Assessment of socio-culturally diverse students: Problems in special education theory-implications for practice. International Journal of Dynamic Assessment and Instruction, 1(2), 86-104.

Bernhard, J. K. (1995). Child development, cultural diversity, and the professional training of early childhood educators. Canadian Journal of Education, 20(4), 415-431.

Bissoondath, N. (1994). Selling Illusions: The Cult of Multiculturalism in Canada. Canada: Penguin Books Ltd.

Bramadat, P (2005). Beyond Christian Canada: Religion and ethnicity in a muliticultural society. In P. Bramadat \& D. Seljak (Eds.), Religion and Ethnicity in Canada (pp.1-25). Toronto: Pearson Longman.

Bowman, L. (Summer, 1991). Catholic religious education in Ontario, opportunities and challenges for the 1990s: Implications for teachers' education. Religious Education 86(3), 362-377.

Callan, E. (2000). Discrimination and religious schooling. In W. Kymlicka \& W. Norman (Eds.), Citizenship in diverse societies (pp. 68-95). Oxford: Oxford University Press.

Carr, P.R. \& Klassen, T.R. (1997). Different perceptions of race in education: racial minority and white teachers. Canadian Journal of Education, 22(1), 67-81. 
Chen, H.J. (2005). The rationale for critical pedagogy in facilitating cultural identity development, Curriculum and Teaching Dialogue, 11-22.

Chan, E. (2006). Teacher experiences of culture in the curriculum. Journal of curriculum studies, 38(2), 161-176.

Chong, K. H. (1998, Fall). What it means to be Christian: the role of religion in the construction of ethnic identity and boundary among second-generation Korean Americans. Sociology of Religion, 59(3), 259-287.

Côte, J. E. (1996). Sociological perspectives on identity formation: the culture-identity link and identity capital. Journal of Adolescence, 19, 417-428.

Cohen-Almagor, R. (2001). "Liberalism and the Limits of Multiculturalism," Journal of Canadian Studies, 36, 80-94.

Cushman, P. (1995). Constructing the self, constructing America: A cultural history of psychotherapy. MA: Addison-Wesley.

Daulatzai, A. (2004). A leap of faith: thoughts on secularistic practices and progressive politics. International Social Science Journal, 56 (182), 565-576.

Dei, G. S. (1995). African studies in Canada: Problems and challenges. Journal of Black Studies, 26(2), 153-171.

Dei, G. S. (1996). The role of Afrocentricity in the inclusive curriculum in Canadian schools. Canadian Journal of Education, 21(2), 170-182.

Dei, G. S. (2000). Towards an anti-racism discursive framework. In G. S. Dei \& A. Calliste (Eds), Power, Knowledge and anti-racism education (pp. 23-39). Halifax: Fernwood Publishing.

Dei, G. S. (2005). The challenge of inclusive schooling in Africa: A Ghanaian case study. Comparative Education, 41(3), 267-289.

Dolmage, W. R. \& Dickinson, G. (1996, Fall). Education, religion and the courts in Ontario. Canadian Journal of Education, 21(4), 363-373.

D'Souza, M. O. (2000). Religious particularism and cultural pluralism: The possible contribution of religious education to Canadian political identity. Religious Education, 95(3), 234-250.

Durkheim, E. (1915). The elementary forms of the religious life. London: Gorge Allen \& Unwin Ltd.

Ebaugh, H. R. \& Chafetz, J. S. (2000). Religion ad the new immigrants: Continuities and adaptations in immigrant congregations. Walnut Creek, CA: AltaMira Press. 
Fleras, A., \& Elliot, J.L. (2002). Engaging Diversity. Multiculturalism in Canada._Nelson: Thomson Learning.

Fraser, N. (1992). Rethinking the public sphere: A contribution to the critique of actually existing democracy. In C. Calhoun (Ed.), Habermas and the public sphere (pp.109-142). Cambridge, MA: MIT Press.

Freire, P. (1978). Education for critical consciousness. New York: Seabury Press.

Giroux, H. A. (1994). Doing cultural studies: Youth and the challenge of pedagogy. Harvard Educational Review, 64(3), 278.

Giroux, H. A. (2003). Spectacles of race and pedagogies of denial: Anti-Black racist pedagogy under the reign of neo-liberalism. Communicative Education, 52(3/4), 191-211.

Giroux, H.A. \& McLaren, P. (1992). Writing from the margins: geographies of identity, pedagogy, and power. Journal of Education, 174(1), 24p.

Gokulsing, M. K. (2006, July). Without prejudice: An exploration of religious diversity, secularism and citizenship in England (with particular reference to the state funding of Muslim faith schools and multiculturalism). Journal of Educational Policy, 21(4), 459470.

Guttman, A. (1992). Introduction. In C. Taylor, Politics of recognition: An essay. Princeton, N.J.: Princeton University Press.

Hammond, P. E. (1998). Religion and the persistence of identity. Journal of the Scientific Study of Religion, 27(1), 1-11

Harper, H. (1997). Difference and diversity in Ontario schooling. Canadian Journal of Education, 22(2), 192-203.

Herbert, D. (2003). Religion and civil society: Rethinking public religion in the contemporary world. London: Ashgate.

Hermans, H.J. (2003). The construction and reconstruction of dialogical self. Journal of Constructivist Psychology, 16, 89-130.

Holms, M. (1995). Common schools for a secularist society. Canadian Journal of education, 20 (3), 284-294

hooks, b. (1994). Teaching to transgress. Education as the practice of freedom. New York: Routledge

Howard, C. T. (2003). Culturally relevant pedagogy: ingredients for critical teachers' reflection. Theory into practice, 43(3), 195-202. 
Ibrahim, A. (2000). "Whassup Homeboy?" Black/Popular culture and the politics of "Curriculum Studies". Devising an anti-racism perspective. In G. S. Dei \& A. Calliste (Eds), Power, Knowledge and anti-racism education (pp. 57-72). Halifax: Fernwood Publishing.

Ivanov, A. (1996). Balkans divided: nationalism, minorities and security. New York: Peter Lang.

Khaled, A.E.F. (2004). Islam and the challenge of democracy. Boston: Princeton University Press.

Keane, J. (2000). Secularism? The Political Quarterly, 71(1), 5-20.

Kelley, N. \& Trebilcock, M. (1998). The making of the mosaic: A history of Canadian immigration policy. Toronto: University of Toronto Press.

Kilbride, K. M. (2000). A review of the literature on the human, social and cultural capital of immigrant children and their families with implications for teacher education. CERIS Working Paper Series. \#13. 26 pp.

Kymlicka, W. (Ed.). (1995). The rights of minority cultures. Oxford: Oxford University Press.

Kymlicka, W. (1998). Finding our way: Rethinking ethnocultural relations in Canada. Oxford: University Press.

Kymlicka, W. (2001). Education for citizenship, Politics in the vernacular: Nationalism, multiculturalism and citizenship (pp. 293-316). Oxford: Oxford University Press.

Ladson-Billings, G. (1995). But that's just good teaching! The case for culturally relevant pedagogy. Theory into practice, 34, 159-165.

Levinson, M. (1999). The demands of liberal education. Oxford: Oxford University Press.

Loptson, P. (2001). Theories of human nature ( $2^{\text {nd }}$ ed.). Peterborough, Ont.: Broadview Press.

Mead, G. H. (1934). Mind, self and society. Chicago: University of Chicago Press.

McGuire, M. B. (1997). Religion. The social context (4th Ed.). Belmont, CA: Wadsworht Publishing Company.

McLaren, P. (1995). White Terror and Oppositional Agency: Towards a critical multiculturalism. In C. E. Sleeter \& P. McLaren (Eds.), Multicultural education, critical pedagogy, and the politics of difference (pp. 33-70). Albany: State University of New York Press.

Modood, T. (2000). Anti-essentialism, multiculturalism and the 'recognition' of religious groups. In W. Kymlicka \& W. Norman (Eds.), Citizenship in diverse societies (pp. 175-195). Oxford: Oxford University Press. 
Moodley, K. (1995). Multicultural education in Canada: Historical development and current status. In J.A. Banks (Ed.), Handbook of research on multicultural education (pp.801820). New York: MacMillan Publishing USA.

Murtadha, K. (1995). An African-centered Pedagogy in dialog with liberatory multiculturalism. In C. E. Sleeter \& P. McLaren (Eds.), Multicultural education, critical pedagogy, and the politics of difference (pp.349-398). Albany: State University of New York Press.

Ontario Ministry of Education, http://www.edu.gov.on.ca/

Peek, L. (2005, Fall). Becoming Muslim: The development of a religious identity. Sociology of Religion, 66 (3), 215-242.

Procter, J. (2004). Stuart Hall. New York: Routledge.

Rooney, E. (2002). A semiprivate room. A Journal of Feminists Cultural Studies, 13(1), 128156.

Rueda, R., Monzó, L. D. \& Arzubiaga, A. (2003). Academic instrumental knowledge: Deconstructing cultural capital theory for strategic intervention approaches. Current Issues in Education, 6(14), Available: http://cie.ed.asu.ed/volume6/number14/

Scott, D. (1999, Jan.). From moral duty to cultural rights: A case study of political faming in education. Sociology of Education, 72(1), 1-21

Seljak, S. (2003, Spring). Values: The hidden curriculum in Education. Canadian Diversity, 64

Seljak, D. (2005). Education, multiculturalism and religion. In P. Bramadat \& D. Seljak (Eds.), Religion and Ethnicity in Canada (pp.178-200). Toronto: Pearson Longman.

Shapiro, B.J. (1986, Summer). The public funding of private schools in Ontario: The setting, some arguments, and some matters of belief. Canadian Journal of Education, 11(3), 264277.

Sikkink, S. (1999, September). The social sources of alienation from public schools. Social Forces, 78(1), 51-86.

Spinner-Halev, J. (2000). Extending diversity, religion in public and private education. In W. Kymlicka \& W. Norman (Eds.), Citizenship in diverse societies (pp. 68-95). Oxford: Oxford University Press.

Squires, R. C. (2002). Rethinking the Black public sphere: An alternative vocabulary for multiple public spheres. Communication Theory, 12(4), 446-468.

Tastsoglou, E. (2000). Mapping the unknowable: The challenges and rewards of cultural, political and pedagogical border crossing. In G. S. Dei \& A. Calliste (Eds), Power, Knowledge and anti-racism education (pp. 98-120). Halifax: Fernwood Publishing. 
Taylor, C. (1992). Multiculturalism and "The politics of recognition": an essay. Princeton, N.J.: Princeton University Press.

Toronto District School Board (TDSB), http://wnww.tdsb.on.ca/

Tyyskä, V. (2006). Teen perspectives on family relations in the Toronto Tamil community. CERIS Working Paper Series \#45, pp. 46

White, L. (2003). Liberalism, Group Rights and the Boundaries of Toleration: The Case of Minority Religious Schools in Ontario. Canadian Journal of Political Science, 36 (5).

Weber, M. (1946). From Man Weber: Essays in Sociology (Ed.). New York: Oxford University Press.

Yasmeen, A.L. \& Gabriel, C. (2002). Multiculturalism. In A. L. Yasmeen \& C. Gabriel (Eds.), Selling Diversity (pp. 105-128). Toronto: Broadview Press.

Zine, J. (2000). Redefining resistance: towards an Islamic subculture in schools. Race, Ethnicity and Education, 3(3), 293-316.

Zine, J. (2001). Muslim youth in Canadian schools: Education and the politics of religious identity. Anthropology and Education Quarterly, 32(4), 399-423.

Zine, J. (2002, Summer). Inclusive schooling in a plural society: removing the margins. Education in Canada, 42(3), 5p.

Zine, J. (2003). Dealing with September 12: integrative anti-racism and the challenge of antiIslamophobia education, Orbit, 33(3), 39-41.

Zine, J. (2006). Unveiled Sentiments: Gendered Islamophobia and Experiences of Veiling among Muslim Girls in a Canadian Islamic School. Equity \& Excellence in Education, 39, 239252. 
$3-2 \cdot 18$ 